\title{
The Student Voice in Designing a Jewish Studies High School Curriculum: A Case Study
}

\author{
Eli Kohn ${ }^{1, *}$ \\ ${ }^{1}$ Director of Curriculum Development, Lookstein Center, School of Education, Bar Ilan University, Israel \\ *Correspondence: Director of Curriculum Development, Lookstein Center, School of Education, Bar Ilan University, \\ Israel. E-mail: eli@lookstein.org
}

Received: June 11, 2017

Accepted: June 29, 2017 Online Published: August 20, 2017

doi:10.5430/jct.v6n2p18

URL: https://doi.org/10.5430/jct.v6n2p18

\begin{abstract}
In January 2012, a team of curriculum specialists based at Bar Ilan University in Israel were approached by a Jewish day school in Australia to design a new Jewish Studies curriculum for its school. The mandate was to design a curriculum model from first-steps that would form the basis for the new curriculum.

This article demonstrates how combining elements of Fullan's ideas about school partnerships with Schwab's 'commonplaces' concepts can best meet the needs of the school's specific population and ethos. The role of student voice is shown to be critical in curriculum deliberations and decision making. Assumptions made by teachers about what students would want to learn proved, in a number of instances, inaccurate. Our research seems to indicate that the student "commonplace" voice within the design of a new curriculum should be given more consideration in the curriculum design process.

While the research was conducted in a particular school context, the principles learned, specifically re: the place of student-voice, can be applied to school contexts internationally.
\end{abstract}

Keywords: student-voice; curriculum design; collaboration; decision making

\section{Introduction}

In January 2012, a team of curriculum specialists based at Bar Ilan University in Israel were approached by a Jewish day school in Australia to design a new Jewish Studies curriculum for its school. It was felt that the current curriculum was not adequately fulfilling the educational goals of the school. The mandate was to design a curriculum model from first-steps that would form the basis for the new curriculum.

This article describes the process which guided the curriculum design. Utilizing a conceptual model which combines elements of Fullan's ideas about school partnerships together with Schwab's 'commonplaces' concept the project attempted to design a curriculum that best met the needs of the school's specific population and ethos. In particular, the paper emphasises the importance of listening to the views of students in the process of curriculum planning.

\section{Educational Underpinnings for the Curriculum model}

In conceptualizing a new curriculum model for the school we began by looking at a number of key core questions about the overall goals of Jewish education. Questions such as "What should be the profile of the ideal Jewish school graduate" or what values should we be looking to emphasise in this type of religious environment, have been discussed by influential educators particularly over the last 50 years. Scheffler (1992), for example, in describing the problems being faced in Jewish education in modernity writes how the emancipation led to a weakening of religious practice and the place of tradition in the Jewish community.

Many scholars have discussed, particularly over the last 30 years, what should be the purposes of Jewish schooling in modern times.

Fox, Scheffler and Marom (2003), for example, discuss this question in their book "Visions of Jewish Education" which brings together the views of different scholars to this question. Some see the Bible as the most important work to be studied and mastered. Others have a more secular orientation which focuses on the importance of learning Hebrew 
language and history in shaping the ideal graduate of the Jewish school. Another group focuses on the goal of inculcating core values in which the student needs to choose freely between different laws and customs.

Interestingly enough Levisohn (2014) criticizes Fox's emphasis on the monolithic individual graduate and asks us to think about vision as "a set of diverse animating ideas." Our focus should always be on the ways in which animating ideas inform our practice, or the ways they ought to do so. Ideal graduates need to be considered through a multifaceted lens which takes many factors into consideration.

Malamet (2007) offers one further approach as to what he sees as the core mandate of current Jewish pedagogy. He writes that the first goal of our contemporary efforts in any Jewish classroom must be inspiration on the existential level and an anticipation of those most central of student questions:

Why should I care? What does Judaism mean to me? Why should I be learning this? In his view, it is the teacher through what he calls "self- disclosure" who is the most important factor in transmitting Jewish knowledge and values.

Levy (2014) also stresses the importance of the teacher in transmitting the core values of Jewish education, which she believes focuses on the fostering of Jewish identity. . It is she who prepares students to live in the greater world with a deeper understanding of who they are and be given abundant opportunities to cultivate and experiment their Jewishness outside the walls of the Jewish Studies classroom.

However it is the premise of this study that such an important discussion should not be made solely by scholars. A wider audience needs to be consulted which reflects the views of the whole school milieu including parents, students, and school graduates. This project was therefore designed to be cognizant of the different voices within the school population and foster a healthy dialogue between them.

\section{Model Adopted for the Curriculum Framework}

The curriculum team decided to utilize a model which combined Fullan's (1999) partnership curriculum framework which facilitates cooperation between stakeholders within the school and external curriculum experts and Schwab's "commonplace" concept. Schwab identified four groups of participants who should be involved in curriculum deliberations. They include representatives of teachers, students, subject experts and members of the wider community. He suggested that only by bringing these four groups together in meaningful discussions can we form the basis of a strong and viable curriculum.

We purported that this model would be successful in fostering discussion between the different groups within the school's population.

So we began the process by creating a forum by which these parties could be actively involved in the discussion of what should be the end product of a Jewish day school education.

As the process highlighted the importance of student voice in the process of curriculum decision making we first discuss the literature on student participation in curriculum planning. We then provide a background to Australian Jewish schools in order to better understand the mileu in which this study was conducted. The results of the deliberations will best be comprehended within this light.

\section{Student Voice in Curriculum Decision Making}

Specific calls for active student involvement in the curriculum go back at least as far as Dewey (1916) at the beginning of the $20^{\text {th }}$ century, continuing during the student movement in the USA and Europe in the 1960's. Aronowitz (1994) Rogers and Freiberg (1969) and Shor (1992) concur that students should share responsibility for curriculum planning. As Shor argues,

...to reverse this passive experience of learning, education for empowerment is not something done by teachers to students for their own good but is something students co-develop for themselves, led by a critical and democratic teacher' (Shor 1992:20)

Many students are in favour of the chance to participate in designing and managing their own curricula. (Bovil et al.2008; Martyn 2000) Benefits include students discovering "the depth of faculty commitment to their learning" (McKinney at al. 2010:89) and enhanced knowledge about their discipline and the learning process with increased confidence to express their views in academic settings (Delpish et al., 2010). Others report enhancements to group cohesion, collective responsibility and student performance in assessments, as well as staff reports of transformed teaching practices (Bovill et al.2011. 
Brooker and Macdonald (1999), also discuss the importance of paying attention to student voice in curriculum design. But unlike Bovil et al. they discuss student voice in curriculum at the school rather than the university level. They point out how most often in curriculum -making practices in Western schools student voices have generally being marginalized. At best, learners opinions are sought only after significant decisions, like the selection of legitimate contact have already been made and the curriculum has been determined by officially approved persons. Although students are continued central to schooling they are rarely consulted in decision making (Dyson 1995).

Klein (1989) suggests that the curriculum has tended to be something "planned for" and "done to" students. Students voices are mostly heard after the fact, how they viewed their programmes rather than how they contributed to the construction of their programmes.

However post-structuralist analyses has drawn attention to the complexity of multi-layered and contextually reflective identity. As Orner (1992:86) states, "when critical pedagogues call for students to find and articulate their voice, they presume singular, essential, authentic and stable notions of identity.' Although those researchers are said to presume an equality of voice, "all voices within the classroom are not and cannot carry equal legitimacy, safety and power in dialogue as this historical moment."

Others have researched the place of student voice in curriculum design. e,g,Bovill and Bulley (2011). Brooman, Darwent and Primor (2015) in their research on the redesign of a module curriculum, found that listening and responding to the student voice in curriculum development brought tangible benefits including improved mean marks and pass rates which were subsequently maintained. A number of quantitative measurements indicated that students perceptions of the module improved, as well as attendance and the number of student wising to pursue EU careers/postgraduate study. In addition, they point out that focus groups were essential to seeing and understanding the student perspective and thereby more effectively hearing the student voice to influence development. Students added to the process by requiring of staff that they continue the practical outcomes of curriculum design and this dialogical approach brought about tangible, as opposed to illusory, benefits.

However the above research has focused mainly on the design of curriculum in higher education and there is relatively little literature on the place of student voice in the design of high school curriculum.

As the Jewish Studies curriculum is not mandated by the requirements of the State curriculum, the stakeholders had complete freedom to choose the subjects in the curriculum based on the ideal graduate model agreed. But as that model's purpose was to provide direction but not a specific curriculum path, this allowed the stakeholders, and particular students to be open and creative in their choices. Student voice was central to the curriculum decisions that were made.

We now discuss briefly the historical background of Australian Jewry so as to better understand the "milieu" in which the school in our study operates.

\section{Background to Australian Jewish Day Schools}

Australian Jewry is widely considered to be one of the most active Jewish communities in the world. One of its main accomplishments is the creation of a Jewish day school system which is the envy of other communities around the world (Forgasz, P and Munz. M. 2011). Over 50\% of Jewish children in Australia attend Jewish schools. This is a far greater percentage than Jewish schools in the United States, for example. Most of the schools have two main goals: to excel in secular studies so that graduates become productive citizens in the larger society, and to construct strong Jewish religious, cultural, and social identities (Rutland, S. 2007).

In order to assess current issues and challenges facing Australian Jewry in the 21st century, Monash University's Australian Centre for Jewish Civilisation, together with Jewish Care Victoria and the Jewish Communal Appeal in New South Wales, undertook a major "Gen08 study" based on a survey questionnaire, census data, and focus group interviews. The Gen08 study attracted 5,840 responses and based on the data provided, argued,

"The Australian Jewish community is thriving, but like other Diaspora communities it faces significant risks to the continuity of Jewish life" (Markus 2011).

He notes that their lives:

"have been defined by its [Australia's] opportunities and material prosperity."

They belong to a generation characterized by individualism (not community

orientation). Generation Y is skeptical of authority and institutions, culturally 
parochial, supportive of diversity, embarking on personal journeys of self-discovery (Markus 2011, 9)."

While GEN08 has provided extensive quantitative data, there has been very little qualitative research undertaken in regard to the place of Israel and Jewish peoplehood in Australian Jewish day schools. One study, undertaken by Ben-Moshe and Mittelberg (2012) focused on four Melbourne Jewish schools reflecting the different sectors within the community: Bialik College (Traditional), the King David School (Progressive), Mount Scopus Memorial College (Orthodox, although most of its school population is made up of non-practicing Jews) and the Leibler Yavneh College (Orthodox). The researchers used the triangulation method, drawing their data from the schools' curricula, the role of informal education, including Israeli youth educators, and visits to Israel. Their findings were based on interviews and materials provided by the senior staff of the schools, but they did not undertake class observations or student interviews. They presented detailed data from each of the four participating schools, and argued strongly that the schools provide a "holistic approach," drawing on a range of different approaches, both formal and informal, "in a complementary way, nuanced to each school, reflecting its particular political, cultural and religious orientation." They claimed that the "formal and informal are interdependent" and stressed the interconnection among classroom lessons, Zionist camps and school programs in Israel. Overall, they developed a very positive picture of education about Israel in Melbourne. Mittelberg (2013) followed up this study with a detailed analysis of the concept of Jewish peoplehood and the impact of educational interventions. Drawing on data from the GEN08 study, particularly the responses of the 18-44-year-old age group, he argued that educational intervention is significant, regardless of home background. He also stressed the importance of youth movement involvement and visits to Israel in developing a strong Jewish commitment and a sense of belonging to the Jewish people. This is in contrast to Graham's findings (2012), which painted a less positive picture (http://artsonline.monash.edu.au/gen08/education-a-statistical-analysis/).

While these studies have focused on the curriculum of particular areas of the Jewish Studies curriculum of Jewish schools such as the study of Israel and Jewish peoplehood, this present study focuses on the development of a comprehensive Jewish studies curriculum for one school which also incorporates the study of Jewish law, traditions and text. Our emphasis on the process of curriculum design in creating a Jewish Studies curriculum is one that has not been sufficiently researched within the Australian Jewish school milieu.

\section{Challenges faced in the Design of the Jewish Studies Curriculum}

For Jewish schools, the compulsory New South Wales Board curriculum poses challenges regarding Jewish education. The Board's requirements regarding the hours mandated for the general studies curriculum means that there is only about 120 minutes per week devoted to Jewish subject areas. This means that most Australian Jewish day schools, including the one in this study, have sparse time to allocate for their Judaic subjects. While some schools have dealt with this issue by adding time to the daily schedule to include more time for Judaic Studies others have not. These schools express the concern that lengthening the school day to accommodate more time for Judaic subjects may turn away parents who feel that this may have a

detrimental effect on their child's Jewish education. The sparcity of hours is compounded by the fact that there is a shortage of trained Judaic Studies teachers to deliver a quality curriculum. As a result any new curriculum initiatives need to include a serious and structured training professional development program that both strengthens the pedagogic skills of teachers presently teaching in schools and attracts strong candidates to take up teaching positions in the school. This will also raise the status of teaching within the community at large (Kohn 2009).

\section{Initiating the Curriculum Foundations}

Following Schwab's commonplaces model and mindful of Fullan's emphasis on collaboration as key to successful curriculum implementation we attempted to synthesize their approaches in our work. Representatives of the four commonplaces were chosen to be actively involved in the curriculum deliberation process. These included Judaic studies teachers led by the Principal, Dean of Jewish Life and Learning, and Jewish Studies practitioners (teachers); student body representation (students); subject and curriculum experts (subject matter) and representatives of the school board (milieu). Learning from the curriculum development experiences of Holtz (1992), we made explicit the central role of the curriculum expert within these deliberations. Firstly, we acted as facilitators of the process ensuring that timetable benchmarks were successfully implemented. In addition, because of the technical difficulties of organizing on-going meetings with representatives of the commonplaces together, this facilitation included deliberations with representatives of the commonplaces in separate meetings. Through this form of "shuttle diplomacy", (a term coined by Holtz 1992), the facilitators aimed to ensure that the views of commonplace 
representatives were aired and understood by all parties.

At the beginning of the project the facilitators presented participants with a three- stage model for curriculum development. This model, based on the principles of the 'Backward Design' curriculum concept (Covey 1994; Wiggins and McTighe 1998), was particularly suited both to the educational milieu of the Australian national curriculum and the desire of commonplace representatives to clarify for themselves the end goal for students of 12 years of Jewish education.

In the words of Covey, "To begin with the end in mind means to start with a clear understanding of your destination. It means to know where you're going so that you better understand where you are now so that the steps you take are always in the right direction." In the backward design model, the curriculum planner starts with the end, the desired results, and then derives the curriculum from the evidence of learning called for by the attainment expectations and the teaching needed to equip students to perform to meet these attainments.

Applying these ideas to this Australian Jewish day school, we created the following graduated process.

1. Definition of the Ideal School Graduate. School leaders, Jewish and General Studies teachers, student representatives, and school board members were all asked to determine this with particular reference to Jewish Studies. This was presented under four headings:
A. Values
B. Behavior Characteristics
C. Jewish Life Skills
D. Jewish Life Knowledge

These titles matched, quite closely, the Australian Curriculum categories of knowledge, skills and values, but focused more heavily on the 'values' category by placing particular emphasis, reflecting the desire of commonplace participants, on beliefs and values as the central focus of the new framework.

2. Description of the course topics and the time devoted to each.

3. Description of each Jewish Studies curriculum area in terms of content, skills and values.

The initial discussions, which focused on Stage 1, were conducted in 2012-2013. They established the core curriculum areas which would be learned by students.

Our premise was that by defining and agreeing on a common set of curriculum entitlements, educators with various roles, such as heads, teachers, rabbis and learning support staff, share a language about Jewish learning and behaviour, and promote high expectations of pupils that maintain consistent progress in attainment. Moreover, defining the curriculum in terms of what pupils should attain in their Jewish learning would help teachers to cooperate in realizing learning outcomes, and to share criteria for assessing pupils' progress in personal growth and attainment. This paper focuses in Stages 1 and 2 of the consultation.

\section{Consultations on Stage 1-The Ideal Graduate}

Consultations with all stakeholders began in January 2013 to define the school ideal graduate. Participants in the discussion included the Principal, Dean of Jewish Life and Learning, teachers, members of the board and students. The school's mission statement formed the foundation of the deliberations. Through a process of discussion over the next year the following document was agreed uon by all stakeholders as the basis of the new curriculum.

8.1 The Jewish Life \& Learning Ideal Graduate January 2014 Final

'...On three things the world stands: on Torah, on service and on acts of loving kindness' (Avot 1:2)

\section{A. Values, Beliefs and Philosophies}

1) Is committed to Judaism as being relevant and meaningful to one's life

2) Strives towards developing a personal relationship with God

3) Values the principles of Modern Orthodoxy

4) Feels privileged to be part of the chain of Jewish history and has a sense of responsibility to the Jewish people

5) Appreciates and is committed to Zionism and the State of Israel 
6) Values the importance of being caring and responsible members of one's family and the wider community

\section{B. Behavioral Characteristics}

1) Demonstrates a commitment to achieving one's personal best

2) Engages in Jewish practice and ongoing Jewish learning

3) Behaves in a sincere, honest, respectful and courteous manner

4) Displays respect to those of different cultural and religious backgrounds

5) Displays pride and confidence in being a Jewish, Zionist Australian

6) Demonstrates leadership and social responsibility to the community and the world at large

\section{Jewish Life Skills}

1) Is able to perform the requisite commandments associated with the life-cycle, daily practice, Shabbat and festivals

2) Utilizes Jewish ethics and sensibilities when making value judgments, moral choices and life decisions

3) Is able to navigate the siddur with confidence and lead part of the daily services

4) Is able to critically analyze a variety of Jewish sources

5) Is able to read Hebrew fluently and sustain a basic conversation in Modern Hebrew

6) Is able to advocate on behalf of the Jewish people and the State of Israel

\section{Jewish Life Knowledge}

1) Knows the structure and order of the Tanach and Oral Law and is familiar with selected texts

2) Is familiar with major areas of Jewish practice and its meaning

3) Knows the structure, literal and more profound meaning of central prayers

4) Knows laws, themes and key texts pertaining to Jewish festivals and commemorative events

5) Is familiar with major themes and events in Jewish history and the State of Israel

6) Understands Jewish philosophical and ethical approaches to life

This document which identified the traits of the ideal graduate was reached after discussion within each of the commonplace groups. As most statements of mission or intent which are finally agreed upon between different parties, it was borne out of compromise and a culture of 'give and take' which we as curriculum facilitators endeavored to foster between the commonplace groups.

So we better appreciate the exact language arrived at through these discussion, this paper outlines the major areas of disagreement and conversations both within and in-between the various participants.

We will show that the student commonplace voice had a central role in the final decisions made.

\section{Areas of Discussion}

The major issues of discussion were in the following two areas:

1. The relative importance of Hebrew Language in the ideal graduate profile

2. The tension between a skills versus values- based approach to the study of Jewish texts

1. Modern Hebrew

The purpose of studying Hebrew as a spoken language in the curriculum was hotly debated. As one mother commented:

"I am amazed that having learned Hebrew every year my daughter is unable to string together even the simplest of sentences. Knowledge of spoken Hebrew is very important to us."

However the teacher commonplace group had a different view.

'We have so little time to teach the core areas of Jewish content and ethics. Knowing how to have a simple conversation in Hebrew is simply not a top priority." The time we have available needs to be channeled to those topics which will ensure Jewish continuity. That can best be achieved through study of Jewish texts and traditions. 
Students, in their commonplace groups, had a very important voice in these discussions and decision making. In the words of one who expressed the views of most:

"Spoken Hebrew is a wonderful goal in theory but cannot be attained with limited hours of teaching and within an English speaking environment. A few will achieve fluency but the majority will not. we are kidding ourselves if we think that more will be achieved."

Because of all the above issues, and with particular consideration of student voice, the phrase "sustain a basic conversation in Modern Hebrew" rather than Hebrew fluency was deemed to be most realistic within the culture of this school.

\section{Study of Jewish Classical Texts}

Jewish Studies teachers had different views in their deliberations about the goals of learning texts. While all agreed that Bible should be a core text in the curriculum, they disagreed as to what students should achieve by studying them. Some felt that it was the values that needed to be emphasized. In the words of one:

'We kid ourselves into believing that students will attain skills in learning text in their original Hebrew form. Our goal should be to learn these sources in English and concentrate on the lessons to be learned from the text and its meaning to a student living in the $21^{\text {st }}$ century."

Others posited that learners need to be required to study text in depth whether in Hebrew or English. In the words of one:

'We should give our students a challenging learning experience similar to what they get in their general studies classroom. They should be exposed to the richness of Jewish sources and be encouraged to analyse them. Why should they not be given the opportunity to do so?

In order to categorise the differing views of teachers regarding the specific teaching of biblical texts, we utilized what Schremer and Bailey (2001) have called teachers "ideologies" or Holtz (2003) has named teachers' "orientations". "Orientation" as a term encompasses aspects of both the knowledge and belief sides of a teacher's relationship to the subject matter. It includes the individual teacher's motivational drive that would mobilize him to teach the material in a particular direction. Grossman (1993) has described how teachers come to these orientations which she attributes to "a probable combination of personal values and disciplinary training". Schremer and Bailey and Holtz have all made their own categories for the different modes of teacher orientations or ideologies in Bible teaching. These categorizations were important to the design of our model as they helped define the type of teacher-orientations to Bible study we could expect within our diverse group of teachers.

Schremer and Bailey formulated four composite profiles of teaching ideologies into which teachers of Bible Studies could be classified. While they focused specifically on the teaching of Bible, we applied their model to the study of Jewish classical texts in general. They include:
A. Focus on Values and Ethics
B. Focus on Text Study
C. Focus on Identification and Continuity
D. Focus on the Value of Text Study itself

A. Focus on Values and Ethics: The aim of this approach is to teach Jewish texts as a book of instruction regarding the values, ethics morality and behavior that a Jew should learn and practice. The primary focus of teaching Jewish classical texts, according to this ideology is to reveal to students the central values, practices and ethics of Judaism inherent in the narratives and teachings explained by the Rabbinic Sages. The skills of reading, translating and analyzing text are secondary. This approach needs to be distinguished from the "values clarification" approach to moral education, which focuses on the student responding to stated Bible values in a personal subjective way rather than moral imperatives to which the student should aspire. The teacher does not require personal opinions or critical thinking of students because they need to learn the fundamental Torah values first. This ideology or orientation is prevalent among ultra-orthodox Bible educators.

B. Focus on Text Study. The primary focus of teaching of Jewish classical texts in this orientation is to convey to the student the depth and sophistication of these texts as a complex erudite work; to show that it is internally consistent, intricate, poetic, spiritual and profound-the source text of all that comprises Judaism. In order to do this, the teacher focuses on skills such as analysis of language and structure of the text as well as the story themes, images and concepts of social law and ritual. Nechama Leibowitz, professor of Bible at Tel Aviv University during 
the mid-1900's, was a principal proponent of this ideology.

C. Focus on Identification and continuity. For the teacher adhering to this approach, it is of ultimate importance that students see textual study as the foundation for their contemporary identification with topics or ideas that may be reflected in their personal experience or in community participation. The Bible represents our collective memory of what has made Jews different from everyone else. Therefore the curriculum focuses on the birth and development of the people, their history and their customs. All of these topics and issues are shown within the context of contemporary communal and national life. This conveys a sense of self definition and belonging.

D. Focus on the value of text study itself. What is most important in this approach is that today's students value learning Jewish classical texts. The primary goal of teaching is not mastery of text skills or even comprehension of specific content but rather to create an experience that will attach the student to textual learning in a positive way. The teaching approach focuses on those texts that evoke inspiration, excitement, surprise and are wholly engaging to a modern adolescent.

We asked teachers to consider which of the various orientations they found most appealing. Most answered that the first two orientations were dominant for them. The focus of their Jewish text teaching, they identified, was on to Jewish ethics and values and on textual study. Interestingly enough the primary school Jewish studies teachers generally focused their teaching on textual study while the secondary teachers were more concerned with a focus on Jewish ethics and values. Among the latter, there was a general correlation between the perceived level of Jewish identification of their students and the focus of the orientation chosen. Where students are perceived to have little Jewish education or commitment to Jewish practice, secondary Jewish studies teachers generally do not see textual study as their educational goal for the class but rather their teaching focus is to relate to their perceived students' need for a stronger Jewish identification. This finding in the teacher commonplace group is supported by other research in this area (Schremer and Bailey 2001).

What was the view on these issues in the student common place group? Whilst various views were offered there was surprisingly a strong voice for textual study irrespective of their commitment to Jewish practice. In the words of one student:

"Why should we not study the nuances of the text, it is intellectually challenging. We do this in our general studies, why not in our Jewish Studies?

While their teachers had the pre-conceived notion that these students would want a Jewish ethical or values based curriculum focus there was a strong view among students that textual study was an important goal within itself.

The results of these deliberations once again were cognizant of student voice. It was decided that the curriculum would aim to integrate a combination of text skills and discussion of Jewish ethics.

Looking at the wording of the ideal graduate document, and based on the above discussions with particular cognizance of student voice it was agreed that 'familiarity' rather than 'fluency' with classical Hebrew was most appropriate within the culture of the school. But the study of specific text sources was included in the profilestudent voice had an important part to play in this decision.

How might teaching be organized and more detailed aims be formulated to produce the 'ideal graduate' outcomes?

There was general consensus that the descriptions written in the ideal graduate attributes can be achieved both within and outside the classroom setting. Teaching and learning would include at least one or more of the ideal group descriptions.

The curriculum would be designed so that two periods of 60 minutes per week is allocated to Jewish Studies for children in Years 7-10 (12-15 year olds). This would allow the delivery of a basic curriculum within the confines of the requirements of the State's general studies curriculum.

\section{Consultations on Stage 2 -Topics and Themes to be learned in the Jewish Studies High School curriculum}

In February 2015, we visited the school again to begin a process of defining the subjects to be taught in Jewish studies based on the stage 1 consultations and the Ideal graduate model. As in stage 1- the process was guided by the Schwab commonplace model which involves input from various stakeholders including teachers, students, curriculum expert and milieu representation.

The discussions aimed to identify the content of the units of learning with particular reference to the study of Bible, 
Jewish laws and traditions.

Two conceptual models for curriculum development were considered, one focusing on specific books mostly from the Bible and the other based on themes. The advantages and disadvantages of each model were presented to stakeholders for discussion.

As we shall detail below, special attention was given to "student voice" in these discussions and subsequent focus groups of students took place in the weeks following. As a form of qualitative research, focus groups allow for interaction of group members to produce data and insights that would be less accessible without the interaction found in a group (Morgan 1997).

About forty students from various year levels took part on these focus groups. In each focus group there were between 6-10 students.

Questions posed to the students included "what subjects would you like to learn about in Jewish Studies"? Which subjects of the curriculum do you think are important? Why do you think the chosen subject area is important? Students were also asked to prioritise their choices. As part of this discussion a list of various Jewish studies subject were presented including:

- Jewish festivals

- Prayer

- Jewish rituals like Shabbat, Blessings, and keeping kosher

- Jewish Ethics and Values e.g. respecting parents, speaking with respect and honesty, value of life

- Jewish Philosophy-Belief in God

- Biblical and Rabbinic texts

- Jewish life cycle, marriage, divorce death etc.

There was general agreement between the stakeholders that the subjects of the curriculum should be thematic rather than follow a particular Biblical or rabbinical text. The theme was to be the focus and the text used to elucidate the theme rather than the other way round.

So which of the above themes were deemed important? The curriculum consultant and teacher "milieu" had assumed, it turned out wrongly, that the students, largely from non-religiously committed homes, would choose those themes which were the most "relevant" to their lives like moral and ethical issues. However there were a large range of opinions in the focus groups. One Year 7 student, for example, said:

"While I don't keep the laws of kosher at home I want to learn those laws so I can choose one day if I want to keep them or not."

And a Year 8 student:

"I go to a Jewish school, I want to learn the rituals as that is why I came here."

Another Year 8 student commented:

"In Mathematics and Science I learn about other things in the world. When I learn about Jewish rituals I learn about who I am."

While this was not the only student voice it was one which had significant support. There were those who focused more on the values ethical side of Judaism but the whole gamut of views were presented by students.

While teachers focus groups had assumed that learning about rituals would be less relevant and meaningful to most students, the student focus group showed otherwise. Student voice, in fact, was very well presented in the final curriculum structure agreed below. The predominance in the new curriculum of themes in Jewish rituals like kashrut, shabbat and prayer was directly influenced by the student commonplace

\section{Structure of the Curriculum}

The final curriculum structure integrated "student voice" which played a significant part in all further curriculum decisions.

The curriculum for individual Year groups has an overarching theme which connects the units within it. The primary factor in deciding the overarching theme has been what stakeholders, and particular student voices, have considered 
as most age appropriate and meaningful for that age group. For example, the concept of what it means to be part of the Jewish people is explored in the Bar mitzvah year in Year 7; a more practical overall theme has been chosen for Years 8 and 9 while a more philosophical theme, deemed more meaningful and relevant to older students, is the focus of Year 10.

Topics (the words topic and theme are used interchangeably below) within these overarching themes have been chosen based on a number of factors including, among others, topics relating to the overarching theme e.g. Modern Orthodoxy within the Jewish Philosophy overarching theme; links between topics e.g. High Holidays is connected to a unit on Self Development; topics that link to other areas in the curriculum e.g. Heroes in the Jewish history curriculum of Year 7; topics that have connections to the calendar e.g. labour laws at Passover time in Year 10.

Texts, including those from Bible, Mishna, Talmud, Jewish Law, Modern Jewish Responsa and Jewish Philosophy are integrated into each theme as appropriate. Based on all of the above, the following is the overall structure of the new Jewish Studies high school program:

\begin{tabular}{|c|c|c|c|c|}
\hline & Term 1 & Term 2 & Term 3 & Term 4 \\
\hline \multirow{4}{*}{$\begin{array}{l}\text { Year } 7 \text { (Jewish } \\
\text { People) }\end{array}$} & \multirow{4}{*}{$\begin{array}{l}\text { Origins of People } 1 \\
\text { beginning of Moses's } \\
\text { life-first leader of the } \\
\text { Jewish people }\end{array}$} & \multirow{2}{*}{$\begin{array}{l}\text { Origins of People } 2 \\
\text { (10 Commandments }\end{array}$} & Origins of People 3 & \multirow{4}{*}{$\begin{array}{l}\text { Origins of People } 4 \\
\text { Entering land (end } \\
\text { of Moses's life) } \\
\text { Connection } \\
\text { between people and } \\
\text { the land of Israel }\end{array}$} \\
\hline & & & relevant & \\
\hline & & focus on Honouring & themes: looking & \\
\hline & & $\begin{array}{l}\text { Parents } \\
\text { and Shabbat (Candle } \\
\text { lighting } \quad \text { Shabbat } \\
\text { Songs) }\end{array}$ & $\begin{array}{l}\text { atter the property of } \\
\text { others. } \\
\text { lost property }\end{array}$ & \\
\hline \multirow{3}{*}{$\begin{array}{l}\text { Year } 8 \text { (Jewish } \\
\text { Practice) }\end{array}$} & Relationship with & Kashrut (kosher & Relationship & Prayer and \\
\hline & $\begin{array}{l}\text { Others: Love your } \\
\text { neighbour }\end{array}$ & $\begin{array}{l}\text { animals keeping } \\
\text { kosher at home) }\end{array}$ & & \\
\hline & Charity & Blessings & Proper Speech & \\
\hline $\begin{array}{l}\text { Year } 9 \text { (Jewish } \\
\text { Life) }\end{array}$ & $\begin{array}{l}\text { Lifecycle (Birth, } \\
\text { Marriage, love and } \\
\text { relationships, } \\
\text { Divorce, Death) }\end{array}$ & $\begin{array}{l}\text { Jewish life in Israel } \\
\text { and other Jewish } \\
\text { communities in the } \\
\text { world }\end{array}$ & $\begin{array}{l}\text { The Message of the } \\
\text { High holidays: } \\
\text { Self -Development }\end{array}$ & $\begin{array}{l}\text { Relationship with } \\
\text { Others } \\
\text { Business Ethics, } \\
\text { Copyright }\end{array}$ \\
\hline $\begin{array}{l}\text { Year 10 } \\
\text { (Jewish } \\
\text { Philosophy } \\
\text { and Ethics) }\end{array}$ & $\begin{array}{l}\text { Medical Ethics } \\
\text { (value of life and } \\
\text { body, e.g. organ } \\
\text { transplants) }\end{array}$ & $\begin{array}{l}\text { Purpose of Mitzvot } \\
\text { e.g. } \\
\text { (Philosophical } \\
\text { aspects) }\end{array}$ & $\begin{array}{lr}\text { Jewish } & \text { Philosophy } \\
\text { Science } & \text { and } \\
\text { Religion } & \end{array}$ & $\begin{array}{l}\text { Israel (e.g. } \\
\text { Dilemmas Jewish } \\
\text { attitude to War and } \\
\text { Peace) }\end{array}$ \\
\hline
\end{tabular}

\section{Concluding Thoughts}

Four years after beginning the process stage 1 and stage 2 have been completed and the school is well into stage three-the writing of the curriculum units themselves. It is time to reconsider the path we took and think about its ramifications both for this project in particular but for other curriculum projects as well. Some reflections include:

1. Utilizing the curriculum principles of Fullan and Schwab, it is possible to design a relevant and vibrant curriculum which allows for all stakeholders to be partners in the process. The Jewish Studies high school curriculum is being written and is supported by all the various constituencies who have been party to the discussions from the outset. The fact that students and teachers "voices" have been listened to throughout has been mentioned by them as being a key factor for the success of the project thus far.

2. This collaborative model however has its downsides too. The attempt to find consensus within and between the groups can result in the formulation of statements that may not be easy for some groups to accept. For example, agreement to adopt a thematic rather than a text based option, while being the majority view, is not fully accepted by those in the minority camp. 
3. While the focus of this project has been on the formal curriculum, attention should be made in such processes to integrate experiential and family education as well. These may include, among others, the organization of school camps on the weekend and summer vacations; family study evenings to complement the curriculum being studied in school; lectures to parents on topics being studied in their child's curriculum. Such an integrated perspective will help to foster the process and assist with the achievement of the learning outcomes.

4. As we have seen, within the constraints of a demanding general studies curriculum time has to be found to increase the minimum time allotment for Jewish Studies As Zeldin (1998) has posited integrating Jewish and general studies allows for better utilization of available time. For example, the study of locations in Israel can be taught through the general studies geography curriculum rather than the Jewish Studies curriculum where time is so limited. However, as Pomson (2001) has posited. there are weaknesses in the integration model. In particular, the model of integration requires the buy in of teachers to make it work. Integration is not only a curriculum design model but it is a way of thinking as well. An integrated curriculum cannot be delivered without integrative teachers. Training integrated teachers is complicated particularly because there are few programs that prepare teachers who are not exclusively Jewish studies teachers or teachers in other disciplines.

5. The importance of student voice in the curriculum development process cannot be over-emphasised. Students have a lot to say about what they want to learn about their religion and why they want to learn it. This process has shown that listening to their voice can make for a richer and more relevant curriculum. As has been noted, assumptions were made by teachers about what students would want to learn that proved in a number of instances inaccurate.

In fact, the student "commonplace" voice within the design of a new curriculum may be the most important of all.

\section{References}

Atkins E. (1997). The Predicaments in Curriculum Deliberation. In N.C. Burbules \& D.T. Hansen (Eds.), Teaching and its Predicaments. Boulder, CO: Westview Press

Ben-Moshe, D., \& Mittelberg D. (2012). The place of Israel and Jewish peoplehood in Jewish education in the Diaspora: An Australian case study. In Paths in pluralistic Jewish education (ed.). Nurit Chamo, and Yuval Dror, 58-90. Tel Aviv: The Mofet Institute, Tel Aviv University.

Bovil C., \& Bulley, C. J. (2011). A model of active student participation in curriculum design: exploring desirability and possibility. In: Rust C. (ed.), Improving Student Learning (18) Oxford Brookes University: Oxford, pp.176-188.

Brooker R., \& Macdonald D. (1999). Did we hear you? Issues of student voice in a curriculum innovation. Journal of Curriculum Studies, 31(1), 83-97. https://doi.org/10.1080/002202799183313

Brooman S., Darwent S., \& Pimor A. (2015). The student voice in higher education curriculum design: is there value in listening? Innovations in Education and Teaching International, 52(6), 663-674.

Connelly F.M., \& Clandinin D.J. (1988). Teachers as Curriculum Planners: Narratives of Experience. New York; Teachers College Press.

Dyson, B.P. (1995). Students voices in two alternative elementary physical education programs. Journal of Teaching in Physical Education, 14(4), 394-407. https://doi.org/10.1123/jtpe.14.4.394

Floden RE. (1997). Reforms that Call for Teaching More Than You Understand. In: Barbules NC and Hansen DT (eds.), Teaching and Its Predicaments. Colarado: Westview Press. pp. 11-28.

Forgasz, P., \& Munz. M. (2011). The Jewel in the crown of Jewish education in Australia. In Helena Miller, Lisa D. Grant, and Alex Pomson (eds.), International handbook of Jewish education, II, 1125-1140. New York: Springer. https://doi.org/10.1007/978-94-007-0354-4_61

Fox S. (1972). A Practical Image of "The Practical". Curriculum Theory Network, 10, 49. https://doi.org/10.2307/1179217

Fullan M. (1997). The Meaning of Educational Change. New York: Teachers College Press.

Graham, D. (2014). The Jewish population of Australia: Key findings from the 2011 census. Melbourne: Monash 
University and the Jewish Communal Appeal.

Holtz B. (1992). Making the Practical Real: The Experience of the Melton Research Center in Curriculum Design: In: Studies in Jewish Education 6. Jerusalem: Magnus Press.

Holtz B. (2003). Textual Knowledge: Teaching the Bible in Theory and in Practice. New York: JTS Press.

Kauffman, Johnson, Kardos, Liu \& Peske. (2002). "Lost at Sea": New Teachers Experiences with Curriculum and Assessment. Teachers College Record, 104, 273-300. https://doi.org/10.1111/1467-9620.00163

Kemmis S., \& McTaggart R. (1988). The Action Research Planner. Geelong: Deakin University Press.

Kirk, D., \& Macdonald D. (2001). Teacher Voice and Ownership of Curriculum Change. Journal of Curriculum Studies, 33(5), 551-567. https://doi.org/10.1080/00220270010016874

Klein, M.F. (1989). Curriculum Reform in the Elementary School: Creating your own Agenda New York: Teachers College Press.

Kohn, E. (2009). The Impact of Community on Curriculum Decision Making in a North American Jewish Day School. In A. Pomson and H. Deitcher (eds.), Jewish Day Schools Jewish Communities Oxford, 255-270.

Lamm, N. (1990). Torah Umadda: The encounter of religious learning and worldly knowledge in the Jewish tradition. Northvale, N.J.: Jason Aaronson

Lasker, A. A. (1976-1977). Parents as partners: Report of a research project. Impact 35.

Levisohn, J.A. (2014). To go from Vision to Practice: Jewish Educational Leadership, 13(1), 4-8.

Levy, S. (2014). Teacher Perceptions of A Successful Jewish School Graduate. Jewish Educational Leadership, 13(1), 21-23.

Malamet, E. (2007). Jewish Education in the Post-modern world. In Grumet. Z (ed.), Jewish Education in Transition. Teaneck, N.J. Ben Yehuda Press.

Markus, A. (2011). Jewish continuity. Melbourne: Monash University Press.

Morgan, D. (1997). Focus groups as Qualitative research. Qualitative Research Methods, 16, 2-70. London. Sage Publications. https://doi.org/10.4135/9781412984287

Pomson, A. (2001). Knowledge that Doesn't Just sit there: Considering a re-conception of the curriculum in integration of Jewish and general studies. Religious Education, 96(4), 528-54. https://doi.org/10.1080/003440801753442410

Rosenak, M. (1987). Commandments and Concerns: Jewish Religious Education in Secular Society. Philadelphia, Jewish Publication Society.

Rutland, S. (2007). Australia. In Israel, the diaspora and Jewish identity, In Danny Ben-Moshe, and Zohar Segev (eds.), 254-267. Brighton: Sussex Academic Press.

Schremer, O., \& Bailey, S. (2001). Curriculum: Real Teachers in Focus-A Study in Jewish Education. Bar Ilan University: Graphit Press.

Schwab J. (1982). Science, Curriculum and Liberal Education. Chicago: University of Chicago Press.

Schwab J. (1983). The Practical 4: Something for Curriculum Professors to Do. Curriculum Inquiry, 13, 240. https://doi.org/10.1080/03626784.1983.11075885

Wiggins G., \& McTighe J. (1998). Understanding by Design. Association of Supervision and Curriculum Development (ASCD) Alexandria VA.

Zeldin M. (1998). Integration and Interaction in the Jewish Day School. In R. Tornberg (ed.), The Jewish Educational Leader's Handbook (Los Angeles, 1998) 579-90. 